\title{
Paradigm of International Exchange Students in Encountering Culture Shock Stages
}

\author{
Rafi'ah Nur (D) $\triangle 1$ and Suhria (D) 2 \\ ${ }^{12}$ Universitas Muhammadiyah Parepare, Indonesia \\ $\square$ Corresponding Author: Rafi'ah Nur, E-mail: rafiahnur@yahoo.com
}

\section{ARTICLE INFORMATION ABSTRACT}

Received: December 18, 2020

Accepted: February 01, 2021

Volume: 3

Issue: 2

DOI: $10.32996 /$ ijels.2021.3.2.11

\section{KEYWORDS}

Multiculturalism, Cross-Cultural

Communication, Culture Shock,

Students Exchange
Globalization can help people gain knowledge and improve learning about how a diversity of the cultures does not cause any conflict, misunderstand, and share knowledge across the culture peacefully. It can be termed as cross-cultural communication. Based on this paper's aims, this article discussed the theory of multiculturalism (cultural diversity), cross-cultural communication, the types of culture shock, the cases of culture shock experience such as the stages of culture shock and reverse culture shock. Thus, this study aims to discuss the theory of multiculturalism and an overview of culture shocks experienced by the student exchange program. As a result, shock culture experience is found by most of the people who live for some duration times. However, they will face reverse culture shock when returning to their home country, even though some returnees do not experience it.

\section{Introduction}

Worldwide, it is mentioned that there are 195 territories officially known as countries nowadays (KC \& Lutz, 2017). Each country has its languages, customs/traditions, food, ethnic, clothing, beliefs, and sovereign system, termed as culture (Kottak, 2011 p. 28). Culture is understood as a natural social psychological concept constructed and transmitted through learning and copying the behaviour and beliefs from one generation to another. The psychological structure and cultural spirit caused national identity in every country from a particular social community, and the eternal historical increase (Erbaş, 2013).

This cultural variation in each region or country is created because of demographic and climate change differences (Shi, Visschers, \& Siegrist, 2015). Further, it happened because of the variance of life needs, social norms from ancestors, and natural resources in each region (Roos, Gelfand, Nau, \& Lun, 2015). This cultural variation is called cultural diversity or multiculturalism (Erbaş, 2013). Thus, the world is multicultural. It is caused by some factors like international trade (Roads, n.d.), colonization (Sá \& Aixelà, 2013), intermarriages between countries (George, Ukpong, \& Imah, 2014), immigrants or even refugees that settled in the new environment (UNESCO, 2009). This diversity indeed needs to be understood to avoid unpleasant feelings among the community all over the earth (Azimi, 2013).

Besides, globalization is potentially mobilizing cultural diversity and spreading its knowledge to being conceived by each cultural community. The fastest mobilization tool for globalization is technology (UNESCO, 2009).Information technology can help people gain knowledge and improve learning about how a diversity of the cultures does not cause any conflict, misunderstand, and share knowledge across the culture peacefully. It can be termed as cross-cultural communication. Cross-cultural commutation can be defined as the way of creating and sharing the meaning or particular codes among people from a different cultural background using several different signs (Allen, 2017).

Cross-cultural communication is used to prevent cultural misconception, misinterpretation, and misunderstanding, either in comprehending a culture through media or visiting the target culture directly (William, 2016). However, there a problem that shows up when people go abroad. It is called culture shock. Culture shock is a profoundly personal experience (Perdesen, 1995). It can affect when one moves to another new cultural environment. Culture shock is commonly seen in international students, refugees, and immigrants (Yolanda, 2015).

K C AL-KINDI CENTER

$\mathbf{R}$ D FOR RESEARCH AND DEVELOPMENT Your gateway to world-class research

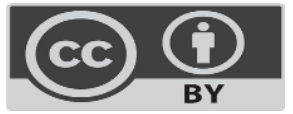

Published by Al-Kindi Center for Research and Development. Copyright (c) the author(s). This open access article is distributed under a Creative Commons Attribution (CC-BY) 4.0 license 
Based on the description above, the researchers intended to provide some theories and cases regarding the effect of multiculturalism, which covers culture shock. This study examines the culture shock experienced by students who temporarily had studied abroad as like students exchange programs by conducting a descriptive qualitative method. Qualitative research aims are to comprehend summarization in colloquial terms of particular events experienced by a person or people (Lambert \& Lambert, 2013). Considering that studying overseas and entering the new cultural environment and society can be an overwhelming task to the students that can experience culture shock while adapting to a new culture (Ernofalina, 2017). This study also discussed the theory of multiculturalism (cultural diversity), cross-cultural communication, the types of culture shock, the cases of culture shock experience such as the stages of culture shock and reverse culture shock. Thus, this study aims to discuss the theory of multiculturalism and investigate the students' exchange program's culture shocks.

\section{Literature Review}

This section consists of the theory of multiculturalism theory, cross-cultural communication concept, and the concept of culture shock.

\subsection{Multiculturalism Theory}

Many researchers have discussed the theory of multiculturalism for years. To begin with, the author highlighted some of them. First of all, multiculturalism is defined as an ideology that refers to accepting cultural diversity in a community and supporting these cultural differences (Schalk-Soekar, van de Vijver, \& Hoogsteder, 2004). Further, (Erbaş, 2013, p. 187) claimed that the differences here included the entire diversity of "ethnic, racial including their intersection or co-articulation with gender and also the debates, controversies, and conflict as well as warmth, and solidarity. A similar viewpoint is stated in Berry's article that multiculturalism is an ideology where society stands to accept or reject diversity (Berry, 2016).

Besides, Bauböck and Rundell (2018) emphasized that multiculturalism is an ideological and normative aspect of ethnicity membership, and recognition of cultural community under no conditions serve as prevention when participating in society. They continued explaining that the term multicultural is when ethnic cultures come together with "political, administrative, geographical, or otherwise accepted partial unit" (Bauböck \& Rundell, 2018). The previous researchers have similarities in defining multiculturalism. It can be said that multiculturalism is an ideology among the diverse society that contributes to and applies certain cultures. On the other hand, society has to pay attention to accepting and respecting the cultures they do not belong.

Although multiculturalism is defined as an ideology, it cannot be denied that the cultural diversity created as the outcome of each nation's historical background. For example, the divergent factors include free-trade, colonialization and wars, and migration (Berry, 2016).. All of the factors' effect can bring new ideas, custom, or culture within it (Zhang, 2019). Free-trade is expanding business development (Yao \& Whalley, 2016). As an example, Roads reported about how trade can spread Indian tradition. In A.D. 400, there was a route called Silk Routes that used to pass by the Asian nation to trade their valuable resources. Indian merchants also thought to expand their trade. They traveled abroad by tracking the route. As a result, people throughout Asia imitated and adapted various Indian traditions. For example, Indian culture affects art, architecture, and dance throughout South and Southeast Asia. Indian influence is especially strong in Thailand, Cambodia, and Java's Indonesian island (Roads, n.d.).

Furthermore, colonialization reflected the creation of the culture of a nation either. A review-based article claimed that cultural diversity in Africa was constructed by colonialization. He stated that even that Africa already has cultural diversity at the very first time. However, colonialism could trigger African origin cultures (Sá \& Aixelà, 2013). The last factor discussing is under colonialization, international migration, and marriages of different countries can be cultural variety factors. Further, UNESCO (2009) reported that the new ideas and cultures were created to negotiate between the host countries and the immigrants. In the beginning, the negotiation will talk about the tolerance of the differences, but as time goes, it may turn into a new cultural expression. An example is a study conducted by Schalk-Soekar et al. (2004). They examined that the multiculturalism and acculturation happen in Dutch natives and four immigrant groups (Surinamers, Antilleans, Turks, and Moroccans), "The attitudes of the Dutch natives and immigrants toward a contact domain (Dutch Involvement with Immigrants) were more similar than attitudes toward a non-contact domain (Cultural Maintenance by Immigrants)" (Schalk-Soekar et al., 2004).

\subsection{Cross-Cultural Communication}

Regarding globalization and cultural diversity, each cluster of society has different cultures. Thus, people should increase their awareness, understanding, and sense of sympathy to avoid prejudice, racism, discrimination, and a minority among the divergent (Erbaş, 2013; Naylor, 1997, p. 1). Moreover, Erbaş (2013) continued that multicultural understanding and respect are the fundamental way to build bridges among communities. This bridge can be termed as cross-cultural communication. 
The concept of cross-cultural communication is needed to enrich competency in communicating with other people. Lott confirmed that although large numbers of gender, skin colour, political beliefs, national origin, and ethnicity background, a cultural community takes part to experience persecution by the majority culture; particular preferences, language, and fear. Communication is needed as the transmission among them (Lott, 2010). It is quite necessary because we sometimes communicate with other people who have different cultures with us as a part of society. According to Erbaş (2013), communicating with other different cultural groups means having a broader free trade and commerce development.

Moreover, Cross-cultural communication can also be defined as a way to communicate where society has to share information among different cultures and social groups to communicate (Tiechuan, 2016). The information should be transferred effectively and efficiently to avoid communication conflicts. The communication conflict could be a misinterpretation, misunderstanding, and miscommunication (Noraini et al., 2014). However, people who always experience different cultural circumstances can define and recognize the problems raised and try to solve them from various perspectives (Erbaş, 2013). Finally, the competence and the knowledge of different cultures play an important role in the cross-cultural communication, the most circumstances that usually need cross-cultural understanding in business field and exchange education program (Tiechuan, 2016).

\subsection{Student Exchange Program}

Studying abroad is a big chance to experience cross-cultural communication. Study abroad improves students' cross-cultural competence (Salisbury, An, \& Pascarella, 2013). As the definition of a Student exchange program, it simply a study program in which students seek education at one international school or university for one or two semesters (ISIC, n.d.).

Moreover, the author has selected some of the students' exchanges: the first is the Erasmus Exchange Program. It is an exchange program carried out within the contracts between European Union countries' higher education institutions and the candidate countries. The European Union supports the program. The program's goal is to provide outgoing learners with new abilities and different experiences. The Exchange program also aims at improving the employment opportunities of outgoing students (Endes, 2015).

The second is the A.F.S. Kennedy-Lugar Youth Exchange and Study (YES) is a full-funded fellowship. It is provided by the U.S. Department of State, addressed to Indonesian High School students to bridge mutual understanding between countries with significant Muslim American people (AFS Indonesia, 2003).

A little bit different from the previous program, this one is called Darmasiswa. It is a scholarship program offered to all international students where Indonesia has a diplomatic relationship. Unlike other studies abroad programs, this one specializes in studying the Indonesian language (Bahasa Indonesia). Recently data reported that the number of the countries participating in more than 111 countries and more since 2015. This program was organized by the Ministry of Education and Culture (MoEC) of Indonesia (Kemendikbud, n.d.).

Thus, it can be said that most of the student exchange program's aim is to build a bridge to understand the diversity and to promote the cultural exchange between the programmer and the candidate. However, it cannot be denied that they will experience culture shock when people enter a new cultural environment. Culture shock is defined in the next item of this paper.

\subsection{Culture Shock}

In this section, the authors provided a similar study that revealed the international students' experiences that study abroad through a student exchange program or any similar program. A similar study proved that exchange students experienced culture shock at various levels, such as initial euphoria, disorientation, adjustment, acceptance, and integration (Ernofalina, 2017).

Culture shock can be defined from the very old perspective. Culture shock is the process of initial adjustment to an unfamiliar environment (Perdesen, 1995). Thus, the culture shock becomes the reaction that the students may have in a new country; the person may feel exhausted to understand and disoriented, and every aspect of life may be difficult (Ernofalina, 2017). Once the culture shock happens, the students can easily become 'lost in translation' due to unfamiliar cultural experiences (Zhou, JindalSnape, Topping, \& Todman, 2008).

\subsection{Stages of Culture Shocks}

Culture shock commonly moves through some stages. Exchange students or foreign learners generally experience this stage of Culture shock. The stages of culture shock once were divided into five stages in his book by Pedersen (1995) entitled "The Five Stages of Culture Shock," as follows: 


\subsubsection{Honeymoon Stage}

This stage indicates by the feeling of "fascinates, adventure, playfulness, discovery, optimism, or excitement," these emotions occur because of "curiosity, interest, self-assurance, and the all of the interesting impression of the host culture" (Perdesen, 1995, pp. 26-27).

\subsubsection{Disintegration Stage}

In this stage, the persons may experience confusion and disorientation, where they finally figure out the differences between their homeland and the host cultures. The sense of being "different, isolated, and inadequate seems permanent, together with depression and withdrawal." These feelings either caused them a failure and self-blame for real fears and weakness (Perdesen, 1995, p. 79).

\subsubsection{Reintegration Stage}

In the third stage, persons will feel anger and blame others for their depression and problems with less sympathy. Instead of finding solutions for misunderstanding, the persons are more likely to judge the host culture and those from the host cultures. In other words, they seem to take a self-protective as strategies for being vulnerable and under attack from the host cultures (Perdesen, 1995, p. 134).

\subsubsection{Autonomy Stage}

After feeling the excitement in stage one, blaming self in stage two, and blaming host cultures in stage three. The persons begin to build up objective, equal, and positive perfectives rather than negative ones. It can be resulting in a new capability to understand the host culture and the person's own cultures. Then, it becomes easier to deal with the diversity (Perdesen, 1995, p. 201).

\subsubsection{Independence Stage}

In this stage, the individual may feel the sense of "belonging, comfortable, settled, accepted, and fluent in both the old and new cultures." The individual's attitude and emotions will be shaped by both mutual and different cultures between the old and new place. They will show their trust and empathy to the host culture's conditions (Perdesen, 1995, p. 245).

In this stage, the individual may feel the sense of "belonging, comfortable, settled, accepted, and fluent in both the old and new cultures." The individual's attitude and emotions will be shaped by both mutual and different cultures between the old and new place. They will show their trust and empathy to the host culture's conditions (Perdesen, 1995, p. 245).

A study of the stages of culture shock by Pedersen reported that exchange students had experienced a higher level of discrimination and homesickness than the local students from different part area in a University of U.S.A. after feeling the excitement. Moreover, the researchers advised the university to treat international students to minimize their discomfort. The university should have a program that can encourage the exchange students to deal with the disintegration or reintegration stage of culture shock (Poyrazli \& Lopez, 2007, p. 277).

However, Ernofalina (2017) also defined the stages of culture shock, which is a bit different from the stages Pedersen, there are only four stages of culture shocks such as (1) Initial Euphoria, the individuals may have a sense of euphoric and be pleased by all new things discovered; (2) Irritation and Hostility, the individuals may deal with the difficult times and conditions, feel discontent, disoriented, madness, and impatience, in this stage also the newcomers will start to complain and blame the host cultures; (3) Gradual Adjustment, in this stages the newcomers will become more comfortable they begin to chill in the situations and conditions and be easy to communicate with the locals in everyday activities. (4) Acceptance and integration, in this stage, the individuals can properly behave in both cultures. They finally have a good understanding of host cultures and move on from the feeling of worry (Ernofalina, 2017, pp. 88-89). On the same tune of Ernofalina, (Grigoryan \& Hunanyan (2019) emphasized that culture shock stages are the honeymoon stage, the disintegration stage, the reintegration stage, and the acceptance stage.

Besides, she identified that culture-shocked affected Indonesian students' lives in various conditions once they studied overseas, such as when the international student is not confident in-class activity, different rules, or education system. However, students finally heal themselves through adjustment, which involves getting used to daily activities, language, school atmosphere, season, weather, food, and interaction among society.

They need different times to pass through the most inconvenienced stage, however (Ernofalina, 2017).

The study conducted above is similar to what the author is interested in studying. But, to investigate the exchange of students' experiences of culture shock, the researchers intended to examine the other theory of culture shock. These stages show the same phases as the other statements above. It is said that an individual who was experiencing culture usually shock step through 
four stages: honeymoon, frustration, adjustment, and adaptation. These stages are common, but some persons could experience them differently (Swedish for Professional, 2020). This below is the picture that shows the phases of culture shock:

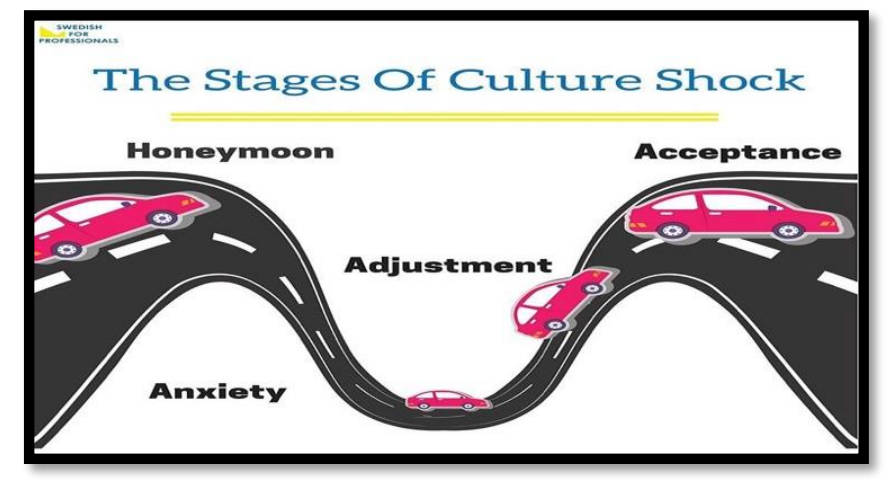

Figure 1: The stage of Culture Shock

\section{(http://swedishforprofessionals.com/4-stages-of-culture-shock/)}

\section{Honeymoon Stage}

The first stage is commonly shown by a greatly positive feeling, such as excitement and joy. The individuals may think that this is the best decision that they ever made. Everything just runs well, great, and organized.

\section{Frustration Stage}

During this stage, the individuals may have a strong feeling of anxiety and dissatisfaction. All of the excitements will be replaced by anger, impatience, sadness, and discomfort. It can also cause miscommunication and misunderstandings that will drive the victims to blame themselves or blame the host cultures.

\section{Adjustment Stage}

The individuals will slowly begin to understand and become familiar with the conditions. In this stage, the individuals are openminded, try to make more friends, and set up everything to feel more at home.

\section{Acceptance Stage}

This acceptance stage is the final stage of culture shock. The individuals will accept both of the similarities and differences between their own cultures and host cultures, adapt to situations, and be part of the speech community (Swedish for Professional, 2020)

Based on some theories above, it can be concluded as a part of cross-cultural experience, culture shock at least has four stages, even though that Pedersen claimed there are five. However, his second and third stages are mixed in one stage of other theories. In this case, the researchers will examine the up-to-date statement of culture shock written by the Swedish for Professional website.

\subsection{Reverse Culture Shock}

A student exchange program is a temporary taking study in another country. Thus, after the program agreement was achieved the due time, the exchange students should come back to their homeland. When they return home, they could experience reverse culture shock because what used to be familiar becomes unfamiliar to feel distressed and readjust to the culture (Kagan, 2019). Reverses culture shock is similar to culture shock. The challenge is to readapt and readjust to the home culture and try to live in again (Kevin F Gaw, 2000).

For example, in a study that looks at the potential reverse culture shock in the workplace when returning to their home country after working abroad, the research was about the daily journal participants' impact impacting reverse culture shock. The report claimed that those who participated in any writing, journals, or blogs had bigger self-reported returned culture shock than those who did not write at all. (Brown, Askay, \& Duffy, 2016).

In this study, the researchers investigated the culture shocks when the exchange students were in a target country. The researchers intended to investigate whether or not the exchange students experienced reverse culture shock as they come home from the study program abroad. 


\section{Methodology}

The research aims to review the theory of multiculturalism and investigate whether the exchange students experienced shock cultures based on the stages explained and experienced reverse culture shock. Thus, the researchers designed a descriptive qualitative method to examine students' culture shock exchange. This method is to discuss and describe the themes of daily life experienced by the students with the specific technique of questioning (Kvale \& Brinkmann, 2009, p. 24). The descriptive qualitative research also focuses on finding the questions of who, what, and where the events or phenomenon experienced from the participants to understand and judge a certain phenomenon (Kim, Sefcik, \& Bradway, 2017). Thus, this study's result is a broad conclusion in the everyday activity of specifically experienced by exchange students (Lambert \& Lambert, 2013).

\subsection{Participants and Instrument}

In collecting qualitative information, the participants are needed deliberately (Chaklader, 2019). In this case, the participants who had studied abroad for a certain period of education time are known as the post-exchange-study phase (Bohman \& Borglin, 2014). Along this line, the researchers found two participants who were corporate purposely. They are post-exchange-study students, as follows:

\begin{tabular}{lll}
\hline Code & Student (A) & Student (B) \\
\hline Status & High School Student & College Student \\
\hline Genre & Female & Male \\
\hline Program & AFS KL-YES Bina Antarbudaya & Darmasiswa \\
\hline School/University & $\begin{array}{l}\text { Senior High School 5 } \\
\text { (SMAN 5 Parepare) }\end{array}$ & Wass Omdurman Ahlia University \\
\hline Home Country & Republic of Indonesia & Sudan \\
\hline Host School/University & McMinnville High School & Universitas Mulawarman \\
\hline Host Country & United Stated of America & Republic of Indonesia \\
\hline
\end{tabular}

Table 1: Participants' Basic Information

The participants were interviewed by giving simple questions regarding the culture shock stages and the reverse culture shock experiences.

\subsection{Instruments}

The researchers conducted an online interview to reach the participants using social media platforms such as WhatsApp to interview the student (A) and Direct Message on Instagram to interview the student (B). The instruments used are interviewed questions or opened-ended questions to gain information about students' experiences. In this way, the questions arranged are to narrate the students' abroad journey regarding culture shock.

\subsection{Data Analysis}

After taking the data from the students' explanations, the researchers transcribed the text of the messages to be analyzed following the four stages of culture shock. The messages were read repeatedly (Bohman \& Borglin, 2014) to identify which events are appropriate with every stage of the culture shock and determine whether the students experienced four stages of shock culture orderly or unorderly.

\section{Results and Discussion}

Based on the theory about culture shock stages, the researchers decided to follow the up-to-date source of shock cultural stages and examined them with the people with whom the author had contact. The stages are the honeymoon, frustration stage, adjustment stage, and adaptation stage (Swedish for Professional, 2020). The first is an Indonesian student coded as a student (A). She was a candidate for A.F.S. Kennedy-Lugar Youth Exchange and Study (YES). She went to McMinnville High School, U.S.A. in 2018-2019, and student (B) had joined the Darmasiswa program. He is from Sudan, Africa, and had a chance to learn the Indonesian language at Mulawarman University, the Republic of Indonesia, in 2017-2018. As a result, as follows:

\subsection{Honeymoon stage}

The feeling of excitement and extreme interest from the first arrival in the target country. Pedersen defined his honeymoon stage as "the emotions typically excitement, stimulation, euphoria, playfulness, discovery, and adventures" (Perdesen, 1995, p. 27). When the students are asked about their experience, student $(A)$ responds,

"The first month is an exited month because everything is a new thing and since I love to be in a new place, meet new people also share culture, make me realize that that is a lot of knowledge and experience." 
Meanwhile, the student (B) responds,

"I had a good time in Indonesia. Indonesian. Indonesian cultures are different from one place to another as long there are many islands, so people are different from place to others."

Student (A) shows up her euphoria in the U.S.A's arrival. It is showed the honeymoon stage that she experienced. On the other hand, student (B) did not feel any excitement when he arrived in Indonesia. He felt exhausted (explained in the next stage), but he said that the honeymoon stages came up after the frustrations passed. He felt good about it. Thus, even if at different times, it clearly can be said that both students experienced the honeymoon stage.

\subsection{Frustration stage}

The frustration stage is a strong feeling of dissatisfaction. The excitement somehow turns into discomfort, anger, impatience, homesickness, overwhelmed, and some other negative feeling. This stage has the same meaning as the Irritation and Hostility stage by Ernofalina (2017) and describes in two stages of Pedersen (1995): disintegration and reintegration stages. The students responded to this stage experience as follows:

Student $(A)$,

"3rd month, I start to feel homesick, it is most likely because of adaptation new culture and making friends, so most kids have their group since they were in kindergarten, so if you want to be included, you are the one who supposed to introduce yourself to them". The student (A) kept continuing,

"I am stress too much because from the beginning we have told that keep in zero expectation.

And student $(B)$ responded,

"The first problem I got is the food so it is very hard for me to change from eating loaves of bread to rice and its very spicy food for me so at the beginning I cannot eat, so I lost weight. I lost about 23kg concerning the people of Indonesia. Indonesian people tend to welcome foreigners, know about them, and ask them questions. However, it is a very different cause for African people because most Indonesian have watched a movie on tv that shows African as traditional people live in jungles. So at the beginning may they surprise to see Africans and they look at you like someone coming from another world, but after knowing you, they surprised and welcomed you and tried to know a lot about you and your country, for me I didn't".

Student (B) also said,

"I feel exhausted. The weather is very hot and warm, and I surprised with House's near the streets before I reached Samarinda and thought, ooh do I will live in a house like this, but after I went to the city center everything is changing, and Samarinda looks good, but the rain is like $\mathrm{mmm}$, it is all the time".

Student $(A)$ experienced shock culture with the symptoms such as homesickness, stress out because of the interaction style in the U.S.A. Meanwhile, student (B) felt exhausted because of the weather and food and feeling discrimination of the Indonesian attitude for the first time. This feeling came up for the first time the student (B) arrived in Indonesia, especially in Samarinda.

\subsection{Adjustment Stage}

They feel more familiar with the circumstances and habits surrounded them, making more friends, and feel more at home. Regarding this stage, student (A) said,

"I have my local coordinator who helps me when through all my things, she kind of a consultant for me and other mom, I love her. I remembered one middle school kid that I used to meet when we were on the school bus. She became my friend because I learned English from her just by talking with her every day. The more I communicated to people, the more I open to the new culture and start to like it so much."

Student (B) responded,

"I just make friends and tour around Samarinda and visit places and try to live like Indonesian and bear the stupid questions like Kamu Sudah mandi and eat spicy food."

In this stage, both students figured out their problems in the previous stages. Student (A) made more friends and tried to be open to the hosts, the same response from the student (B), to make friends, travel a lot, and try to live like Indonesian. This stage is similar to the gradual adjustment stage (Ernofalina, 2017) where the participants felt more comfortable to get engaged with the cultures society, and also similar to the fourth stage by Pedersen (1995) autonomy stage where the participants built up an objective and positive perspective rather than a negative attitude. 


\subsection{Adaptation Stage}

In this final stage, people can accept the custom and imitate the culture. This stage is contributing to the newcomers' integration. For this state the student (A) stated,

"Almost three months I figured it out, English in America so different from British. F.Y.I. I love western food for the first like two weeks. It didn't have the taste I said, but after I like it and my fourth month in America, I don't even want to go back home. American people are the most open-minded person that l ever know. No one ever judges others just based on how they look. I never got bullied. One thing that I can learn that if you keep the problem to yourself and not try to talk to other people, it will make your homesickness worse."

The student (B) stated,

"After I transform to slim, I am playing football, and I feel happy, and I like spicy food now."

In this final stage, it can be seen that how both students finally accept the habit, custom, food, and everything within, which is shown the approximation with the theory of Pedersen (Independent stage) and Ernofalina (Acceptance and Integration stage).

Besides, after asking the participants about the culture shock experiences during studying abroad, the researchers also asked for information regarding reverse culture shock after returning to their home country. Student (A) and student (B), the responses as follows;

Student (A),

"Oh yeah, a lot, this may be sound lame, but the most culture shock is the traffic; also I am kind of afraid when people give me a lift by motorcycle, I feel like I am going to fall because I am not used to seeing it a year."

Student (B),

"No, I just keep everything I had in my head."

Based on the findings, the researchers then figured out the following matrix.

\begin{tabular}{lll}
\hline & \multicolumn{1}{l}{ Culture Shock Stages } & Symptoms \\
\cline { 2 - 3 } Student (A) & Honeymoon stage & Excited \\
\cline { 2 - 3 } & Frustration Stage & Homesick, stressful \\
\cline { 2 - 3 } & Adjustment Stage & More comfortable to make friends \\
\cline { 2 - 3 } & Adaptation Stage & Open-minded \\
\cline { 2 - 3 } & Reverse Culture Shock & Shocking of home cultures \\
\hline \hline & Frustration stage & Exhausted, Discrimination \\
\cline { 2 - 3 } Student (B) & Honeymoon Stage & Feeling good, Surprised \\
\cline { 2 - 3 } & Adjustment Stage & Mappy \\
\cline { 2 - 3 } & Adaptation Stage & - \\
\cline { 2 - 3 } & Reverse Culture Shock & Hore comfoble to make friends \\
\hline
\end{tabular}

Table 2: Findings

In social life, as a part of society, multiculturalism is important. We are not live alone. Thus, as an ideology, multiculturalism can not be denied among the diversity. It grows as the communication we have to participate in cultural circumstances. Effective and efficient communication is needed to avoid any conflict that occurs. Cross-cultural communication should provide good information to reduce misunderstanding, miscommunication, and misinterpretation.

Further, as an impact of cross-cultural communication, culture shock is experienced by job workers abroad or students exchange. The author put the evidence about the stages of culture shock by two students. One is an Indonesian student studying abroad. The other is a student from Sudan who had studied in Indonesia. As a result, in the first stage, they were optimistic. They intended to focus on what they think is positive to experience in the new cultural society, euphoria, and be pleased by all new things they ever met. This stage also may be called Initial euphoria (Ernofalina, 2017). 
In the second stage, they were disorientated in different ways. They took the culture as the source of conflict, where the student (A) felt homesick because the surrounding area is not supported her habit. On the other hand, student (B) feel like there was racism for the first time he arrived in Indonesia, student (B) thought that Indonesian is too overreacting toward African.

The third stage showed that both tried to accept the differences and similarities between their origin and host cultures. It is shown that student (A) was more excited about America than student (B) toward Indonesia. In the last stage, they finally can react normally and properly to society.

However, like culture shock, reverse culture shock is a sense of identity and overall life with low satisfaction and disorientation. Similarly, if an individual or a group experiences high levels of reverse culture shock, they should copy again day by day, and it can end up in stress (Presbitero, 2016). According to the example above, not all returnees experienced reverse culture shock. Probably they will but not affect them so badly like others.

Reverse culture shock shows up as the effect of returning from the target country to the home country. However, it obviously can be said that the reverse culture shock symptoms do not occur in every returnee. Student (A) experienced reverse culture shock, while student (B) did not.

\section{Conclusion}

Based on the results and discussion in the previous part, the researchers conclude that shock culture experience is found by most of the people who live for some duration times. However, they will face reverse culture shock when returning to their home country, even though some returnees do not experience it. The multiculturalism is an ideology among diverse societies contributing and applying certain cultures. On the other hand, society has to pay attention to accepting and respecting cultural differences. Further, multiculturalism can occur as the impact of colonization, migration, or even free-trade.

In this globalization, the opportunity to communicate among different cultures is open widely. Some supported programs are set up to promote every nation's culture. One of them is called a student exchange program. This exchange program allows students to travel and study in another country, mostly fully funded. The biggest issue found that when someone goes to a different cultural society is called culture shock. It will be experienced by most of the people who live for some duration times. Nevertheless, when they return to their home country, they will face reverse culture shock, even though some returnees do not experience it.

\section{References}

[1] Allen, M. (2017). The Sage Encyclopedia of Communication Research Methods.1(4). Thousand Oaks, CA: SAGE Publications, Inc doi: 10.4135/9781483381411 retrieved from https://methods.sagepub.com/reference/the-sage-encyclopedia-of-communication -researchmethods/i3766.xml

[2] AFS Indonesia. (2003). Kennedy-Lugar Youth Exchange and Study (YES) Program. Retrieved from https://afsindonesia.org/yes-program/

[3] Azimi, M. (2013). Cultural Diversity: an Overview. International Journal of Asian Social Science, 3(10), 2147-2151.

[4] Bauböck, R., \& Rundell, J. (2018). Blurred Boundaries: Migration, Ethnicity, Citizenship. Retrieved from https://books.google.co.id/

[5] Berry, J. (2016). Diversity and equity. Cross Cultural and Strategic Management, 23(3), 413-430. https://doi.org/10.1108/CCSM-03-20160085

[6] Bohman, D. M., \& Borglin, G. (2014). Student exchange for nursing students: Does it raise cultural awareness'? A descriptive, qualitative study. Nurse Education in Practice, 14(3), 259-264. https://doi.org/10.1016/j.nepr.2013.11.006

[7] Brown, S., Askay, D., \& Duffy, B. (2016). Running Head: Effects of Intrapersonal Communication on Reverse Culture Shock Effects of Intrapersonal Communication on Reverse Culture Shock A Senior Project Presented to.

[8] Chaklader, M. A. (2019). Understanding Ethnic Identity in the Context of Internal Migration: a Case Study of University Students of Ethnic Minority Origins in Urban Bangladesh. PEOPLE: International Journal of Social Sciences, 5(1), 328-349. https://doi.org/10.20319/pijss.2019.51.328349

[9] Endes, Y. Z. (2015). Overseas Education Process of Outgoing Students within the Erasmus Exchange Programme. Procedia - Social and Behavioral Sciences, 174, 1408-1414. https://doi.org/10.1016/j.sbspro.2015.01.768

[10] Erbaş, İ. (2013). Perception of Cultural Diversity. Academic Journal of Interdisciplinary Studies, 2(11), 186-192. https://doi.org/10.5901/ajis.2013.v2n11p186

[11] Ernofalina, E. (2017). Culture Shocks Experienced by Indonesian Students Studying Overseas. International Journal of Educational Best Practices, 1(2), 87. https://doi.org/10.31258/ijebp.v1n2.p87-105

[12] George, I. N., Ukpong, D. E., \& Imah, E. E. (2014). Cultural Diversity of Marriage Sustainability in Nigeria: Strenghts and Challenges. 2(1), 714. https://doi.org/10.13189/sa.2014.020102

[13] Grigoryan, G., \& Hunanyan, A. (2019). Welcome home , Culture Shock. Scientific Article, (3). Retrieved from http://kantegh.asj-oa.am/2491/

[14] ISIC. (n.d.). Student Exchange Program. Retrieved from https://isic.co.in/study-abroad-3/student-exchange-programs/

[15] Kagan, J. (2019). Reverse Culture Shock. Retrieved from https://www.investopedia. com/terms/r/reverse-culture-shock.asp

[16] KC, S., \& Lutz, W. (2017). The human core of the shared socioeconomic pathways: Population scenarios by age, sex and level of education for all countries to 2100. Global Environmental Change, 42, 181-192. https://doi.org/10.1016/j.gloenvcha.2014.06.004

[17] Kemendikbud. (n.d.). DARMASISWA Indonesian Scholarship. Retrieved from https://darmasiswa.kemdikbud.go.id/ 
[18] Kevin F Gaw. (2000). Reverse culture shock in students returning from overseas. International Journal of Intercultural Relations, 24(2000), 83-104. Retrieved from www.elsevier.com/locate/ijintrel

[19] Kim, H., Sefcik, J. S., \& Bradway, C. (2017). Characteristics of Qualitative Descriptive Studies: A Systematic Review. Res Nurs Health, 40(1), 23-42. https://doi.org/10.1002/nur.21768.Characteristics

[20] Kottak, C. P. (n.d.). Anthropology: Appreciating Human Diversity By. Retrieved from https://pdfs.semanticscholar.org/af0d/74411c6234ca68cd9224c0dda06d1da576a5.pdf

[21] Kvale, S., \& Brinkmann, S. (2009). No Title (2nd ed.). Retrieved from https://books.google.co.id/books

[22] Lambert, V. a., \& Lambert, C. E. (2013). Qualitative Descriptive Research: An Acceptable Design. Pacific Rim International Journal of Nursing Research, 16(4), 255-256. Retrieved from http://antispam.kmutt.ac.th/index.php/PRIJNR/article/download/5805/ 5064

[23] Lott, B. (2010). Multiculturalism and Diversity: A Social Psychological Perspective (I). Retrieved from https://books.google.co.id/

[24] Naylor, L. L. (1997). Culture Diversity in United States (L. L. Naylor, Ed.). Retrieved from https://books.google.co.id/books

[25] Noraini, B., Mohd, B., Zulkifli, Z. B., Maizura, I., Abd, B., \& Kamil, S. B. (2014). a Study on Barriers of Cross-Cultural Communication in Electronic-. The International Journal Of Social Sciences, 27(1), 97-117.

[26] Perdesen, P. (1995). The Five Stages of Culture Shock: Critical Incidents Around the World (1st ed.). Retrieved from https://books.google.co.id/books

[27] Poyrazli, S., \& Lopez, M. D. (2007). An exploratory study of perceived discrimination and homesickness: A comparison of international students and American students. Journal of Psychology: Interdisciplinary and Applied, 141(3), 263-280. https://doi.org/ 10.3200/JRLP.141.3.263-280

[28] Presbitero, A. (2016). Culture shock and reverse culture shock: The moderating role of cultural intelligence in international students' adaptation. International Journal of Intercultural Relations, 53, 28-38. https://doi.org/10.1016/j.ijintrel.2016.05.004

[29] Roads, S. (n.d.). India and China Establish Empires. In East (pp. 177-180). Retrieved from http://www.sps186.org/downloads/basic/727175/ch7_2.pdf

[30] Roos, P., Gelfand, M., Nau, D., \& Lun, J. (2015). Societal threat and cultural variation in the strength of social norms: An evolutionary basis. Organizational Behavior and Human Decision Processes, 129, 14-23. https://doi.org/10.1016/j.obhdp.2015.01.003

[31] Sá, A. L., \& Aixelà, Y. (2013). Cultural Diversity in Africa: Colonial Legacy and Construction of Alternatives . Introduction. Nordic Journal of African Studies, 22(1/2), 1-5. Retrieved from https://njas.fi/njas/article/download/163/153

[32] Salisbury, M. H., An, B. P., \& Pascarella, E. T. (2013). The effect of study abroad on intercultural competence among undergraduate college students. Journal of Student Affairs Research and Practice, 50(1), 1-20. https://doi.org/10.1515/jsarp-2013-0001

[33] Schalk-Soekar, S. R. G., van de Vijver, F. J. R., \& Hoogsteder, M. (2004). Attitudes toward multiculturalism of immigrants and majority members in the Netherlands. International Journal of Intercultural Relations, 28(6), 533-550. https://doi.org/10.1016/j.ijintrel.2005.01.009

[34] Shi, J., Visschers, V. H. M., \& Siegrist, M. (2015). Public Perception of Climate Change: The Importance of Knowledge and Cultural Worldviews. Risk Analysis, 35(12), 2183-2201. https://doi.org/10.1111/risa.12406

[35] Swedish for Professional. (2020). THE 4 STAGES OF CULTURE SHOCK. Retrieved from http://swedishforprofessionals.com/4-stages-ofculture-shock/

[36] Tiechuan, M. (2016). A Study on Nonverbal Communication in Cross-Culture. 4(1), 141-153.

[37] UNESCO. (2009). Investing in Cultural Diversity and Intercultural dialogue. In UNESCO World Report.

[38] William, T. (2016). Cross-Cultural Communication - Avoid Misunderstandings. Retrieved from Linkedin website: https://www.linkedin.com/pulse/cross-cultural-communication-avoid-misunderstandings-todd-bagnall

[39] Yao, D., \& Whalley, J. (2016). The China (Shanghai) Pilot Free Trade Zone: Background, Developments and Preliminary Assessment of Initial Impacts. World Economy, 39(1), 2-15. https://doi.org/10.1111/twec.12364

[40] Yolanda, W. (2015). Culture Shock: Definition, Stages \& Examples. Retrieved from https://study.com/academy/lesson/culture-shockdefinition-stages-examples.html

[41] Zhang, W. (2019). Communication in Teaching of International. 350(Aermt), 91-94.

[42] Zhou, Y., Jindal-Snape, D., Topping, K., \& Todman, J. (2008). Theoretical models of culture shock and adaptation in international students in higher education. Studies in Higher Education, 33(1), 63-75. https://doi.org/10.1080/03075070701794833 